\title{
Promotion of spontaneous diabetes in non-obese diabetes-prone mice by cyclophosphamide
}

\author{
M. Harada ${ }^{1}$ and S. Makino ${ }^{2}$ \\ ${ }^{1}$ Shionogi Research Laboratories, Osaka, and ${ }^{2}$ Aburahi Laboratories, Shionogi Research Laboratories, Kokacho, Kokagun, Shigaken, Japan
}

Summary. Cyclophosphamide promoted the onset of overt diabetes in non-obese diabetes-prone mice of both sexes. Two injections of this agent at 2 weeks apart were necessary to obtain a constant high incidence, although even a single injection was effective in some animals. Clinical symptoms of the cyclophosphamide-induced diabetes were similar to those of the naturally occurring type. The same schedule of cyclophosphamide treatment failed to induce diabetes in non-diabetic mouse strains, such as DS/Shi, Jcl: ICR or in non-obese nondiabetes-prone mice, which suggests that the promotion of diabetes by cyclophosphamide in non-obese diabetes-prone mice is not due to the simple pharmacological action of this agent but to some immunopharmacological action.

Key words: Non-obese diabetes-prone mouse, cyclophosphamide.
The non-obese diabetes-prone (NOD) mouse, which develops spontaneous diabetes of the non-obese type, is one of two sister strains established during the course of breeding of cataractous mice from the Jcl: ICR mouse $[1,2]$. The occurrence of overt diabetes in this strain is sex-related [3]. In the female mice, the disease is observed first at 13 weeks of age and thereafter the number of mice with diabetes increases, the cumulative incidence reaching approximately $75 \%$ at 30 weeks of age. On the other hand, diabetes occurs in a few males only, the cumulative incidence being approximately $10 \%$ at 30 weeks from birth. However, histological examination has revealed that insulitis occurs in almost all the mice of both sexes after 5 weeks of age and is followed by islet atrophy [3]. These histological changes are very similar to those observed in human juvenile-onset diabetes mellitus and spontaneous diabetes in the BB rat [4]. To elucidate the pathogenic mechanism in NOD mice, we started a series of experiments from the immunological standpoint, because recent information has suggested that humoral and/or cell-mediated immunities to pancreatic islets are involved in the production of insulindependent diabetes in man [5-9] and animals $[4,10,11]$. In the first attempt, we examined the effect of cyclophosphamide (CY) on the production of diabetes in NOD mice. This agent is known to enhance some autoimmune diseases, such as experimental allergic encephalomyelitis [12] and streptozotocin-induced diabetes in the mouse [13] probably by impairing suppressor cells.

\section{Materials and methods}

\section{Animals}

NOD mice of both sexes at differing ages were used. The non-diabetic strains used were DS/Shi (inbred, female, aged 8 weeks), Jcl:ICR (closed colony, female, aged 8 weeks, purchased from Clea Japan Inc., Tokyo, Japan) and non-obese non-diabetes-prone (inbred, both sexes, aged 5 weeks) mice. All but the Jcl: ICR mice were bred in our laboratory. The non-obese non-diabetes-prone mouse is a sister strain isolated during breeding of the cataractous mouse [1]. All the mice were kept under conventional conditions at a constant temperature $\left(22-25^{\circ} \mathrm{C}\right.$ ), and fed on commercial diet CA-1 (Clea Japan Inc., Tokyo, Japan) and tap water ad libitum.

\section{Cyclophosphamide treatment}

Cyclophosphamide (CY, $150 \mathrm{mg} / \mathrm{kg}$, Asta, Frankfurt, FRG) was injected intraperitoneally once or twice with a 2-week interval. As the vehicle control, $\mathrm{NaCl}(0.154 \mathrm{~mol} / 1)$ was injected in place of CY. Numbers and ages of CY- or saline-treated mice are shown in Table 1.

\section{Examination of overt diabetes}

The onset of overt diabetes was examined by testing the urinary glucose with Tes-Tape (Eli-Lilly, Indianapolis, Illinois, USA). The animals showing strongly positive coloration $(>$ grade +++ ) were recorded as diabetic mice. Plasma and urinary glucose concentrations of some randomly selected Tes-Tape-positive and negative mice were quantitatively determined by the glucose oxidase method using a commercial kit (Blood Sugar-GOD-Perid-Test, Boehringer-Mannheim-Yamanouchi, Tokyo, Japan) [3]. 
Table 1. Effect of intraperitoneal injection of cyclophosphamide (CY) on the production of overt diabetes in non-obese diabetes-prone and three other strains of mouse

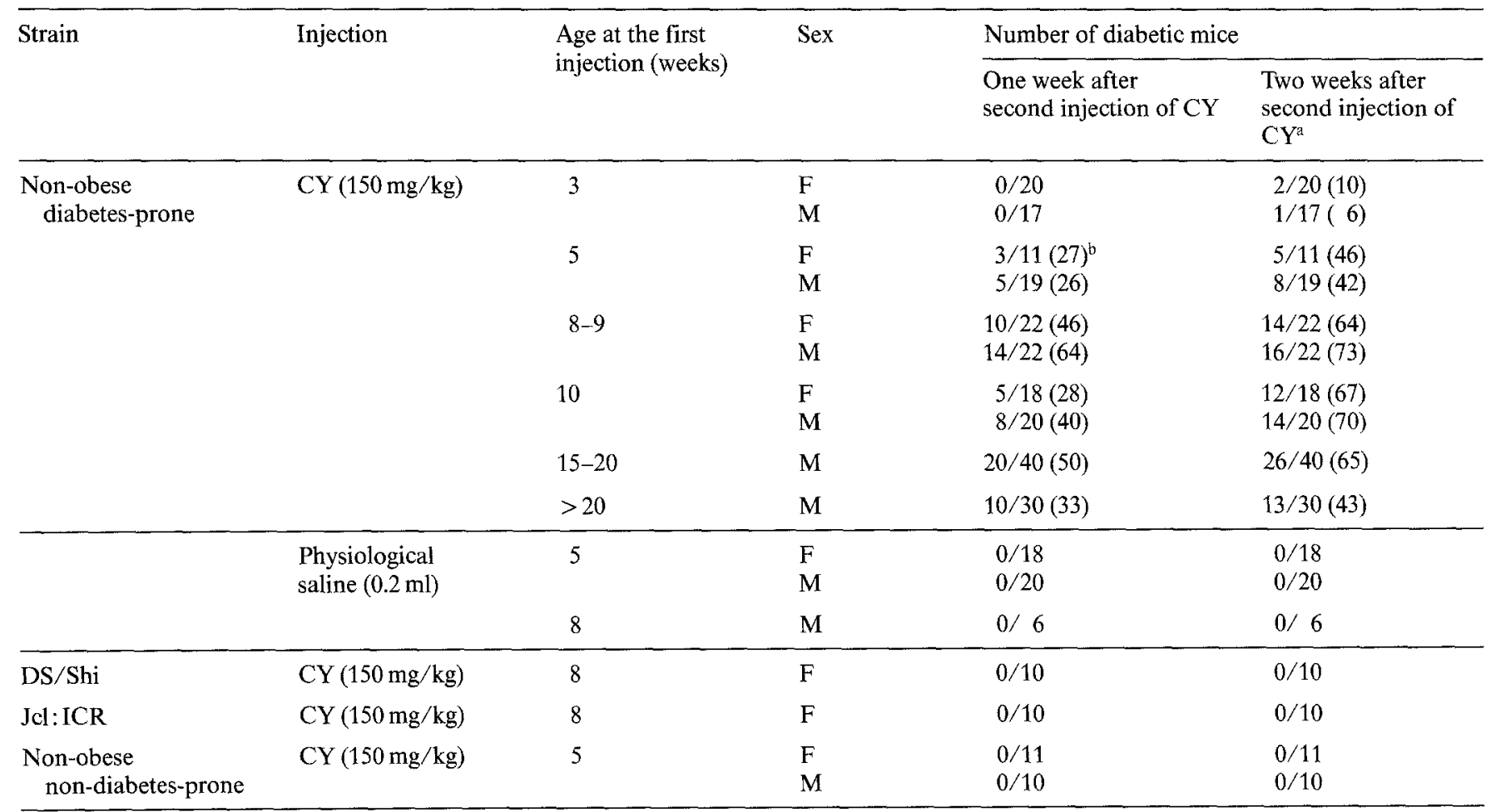

${ }^{a}$ Injections given 2 weeks apart. $\quad{ }^{\mathrm{b}}$ Corresponding percentage given in parentheses

\section{Results}

Overt diabetes was induced in a number of NOD mice injected twice with CY (Table 1). The promotion of pathogenesis was striking in both sexes. The disease was induced in many young females aged 5-9 weeks that otherwise would not have developed spontaneous diabtes so early. Male mice also displayed an incidence comparable with that in females, despite the fact that males rarely develop diabetes spontaneously. The effect of CY did not differ with age, except for the incidence being low in very young mice (aged 3 weeks) in which insulitis was not yet observed. Even a single injection of CY was effective, but the incidence varied with the experiment. To obtain a high incidence more constantly, re-injection at a 2-week interval was necessary. In this case, cumulative incidence attained the maximal level between 1 and 2 weeks after the second injection.

In the control mice treated with physiological saline solution, no promotion of diabetes was observed.

Determination of plasma and urinary glucose concentrations confirmed the above results using Tes-Tape. Plasma glucose levels of randomly selected agematched ( $8-9$ weeks) diabetic and control mice of either sex were $36.6 \pm 5.9 \mathrm{mmol} / 1$ (mean $\pm \mathrm{SD}, n=6$ ) and $9.1 \pm 1.9 \mathrm{mmol} / 1(n=4)$ respectively 2 weeks after the second injection of CY or saline solution. Urinary glucose levels of these diabetic and control mice determined at the same time were $590.8 \pm 35.3 \mathrm{mmol} / 1$ $(n=6)$ and $4.1 \pm 0.3 \mathrm{mmol} / 1(n=4)$ respectively. In addition, consumption of food and water and the urine volume increased greatly in the diseased animals. Loss of body weight and wasting were also pronounced. The mice weighed 25 to $30 \mathrm{~g}$ before the onset of diabetes and less than $20 \mathrm{~g}$ at the time of death.

In contrast with NOD mice, the three normal strains of mouse, i.e., DS/Shi, Jcl:ICR and non-obese nondiabetes-prone mouse, did not become diabetic after the same CY treatment (Table 1).

\section{Discussion}

The present experiment demonstrates that $\mathrm{CY}$ treatment promotes the onset of diabetes in NOD mice. Because the same treatment failed to induce the disease in three other strains, promotion of the pathogenesis is unlikely to be due simply to the pharmacological action of this agent. Induction of overt diabetes by CY seems to require some pathological background unique to both sexes of NOD strain aged more than 5 weeks; e. g., insulitis. CY may potentiate the immunological damage of pancreatic islets in this strain, although the development of anti-islet autoimmunity is somewhat controversial at present. Support for this speculation comes from - the well-documented information that CY can enhance the immune response to various immunogens including proteinous antigens [14-16] and foreign red blood cells 
$[17,18]$ by depleting suppressor $T$ lymphocytes or their precursors. More closely related findings show that CY converts resistant mouse strains into susceptible ones to some autoimmune diseases, such as experimental allergic encephalomyelitis [12] and streptozotocin-induced diabetes [13], thus offering more support for our speculation.

Acknowledgements. We gratefully acknowledge the valuable advice of Drs. K. Katagiri and Y.Hayashi. We are also very grateful to Mr. M. Takeuchi, Mr. M. Matsumoto and Mrs. K. Kunimoto for their technical help.

\section{References}

1. Ohtori H, Yoshida T, Inuta T (1968) "Small eye and cataract", a new dominant mutation in the mouse. Exp Anim 17: 91-96 (in Japanese)

2. Ohtori H, Yoshida T (1975) The CTS mouse. Exp Anim 24: 123 (In Japanese)

3. Makino S, Kunimoto K, Muraoka Y, Mizushima Y, Katagiri K, Tochino $Y(1980)$ Breeding of a non-obese, diabetic strain of mice. Exp Anim 29: 1-13

4. Nakhooda AF, Like AA, Chappel CI, Wei CN, Marliss EB (1978) The spontaneously diabetic Wistar rat (the "BB" rat). Diabetologia 14: 199-207

5. Bottazzo GF, Florin-Christensen A, Doniach D (1974) Islet-cell antibodies in diabetes mellitus with autoimmune polyendocrine deficiencies. Lancet 2: 1279-1283

6. Irvine WJ, McCallum CJ, Gray RS, Campbell CJ, Duncan LJP, Farquhar JW, Vaughan H, Morris PJ (1977) Pancreatic islet-cell antibodies in diabetes mellitus correlated with the duration and type of diabetes, coexistent autoimmune disease and HLA type. Diabetes 26: 138-147

7. Lernmark A, Freedman ZR, Hofmann C, Rubenstein AH, Steiner DF, Jackson RL, Winter RJ, Traisman HS (1978) Islet-cell-surface antibodies in juvenile diabetes mellitus. New Engl J Med 299: 375-380

8. Nerup J, Andersen OO, Bendixen G, Eglaberg J, Poulsen JE (1971) Anti-pancreatic cellular hypersensitivity in diabetes mellitus. Diabetes 20: 424-427
9. MacCuish AC, Jordan J, Campbell CJ, Duncan LJP, Irvine WJ (1974) Cell-mediated immunity to human pancreas in diabetes mellitus. Diabetes 23: 693-697

10. Like AA, Butler L, Williams RM, Appel MC, Weringer EJ, Rossini AA (1982) Spontaneous autoimmune diabetes mellitus in the BB rats. Diabetes 31 (Suppl 1): 7-13

11. Haspel MV, Onodera T, Prabharker BS, McClintock PR, Essani K, Ray UR, Yagihash S, Notkins AL (1983) Multiple organ-reactive monoclonal autoantibodies. Nature 304: 73-76

12. Lando Z, Teitelbaum D, Arnon R (1980) Induction of experimental allergic encephalomyelitis in genetically resistant strains of mice. Nature (Lond) 287: 551-552

13. Kiesel U, Greulich B, Marx-Soho Moume, Kolb H (1981) Induction of experimental autoimmune diabetes by low-dose streptozotocin treatment in genetically resistant mice. Immunol Lett 3: $227-230$

14. Taniguchi M, Tada T (1971) Regulation of homocytotropic antibody formation in the rat. IV. Effect of various immunosuppressive drugs. J Immunol 107: 579-585

15. Chiorazzi N, Fox DA, Katz DT (1976) Hapten specific IgE antibody responses in mice. VI. Selective enhancement of IgE antibody production by low doses of $\mathrm{X}$-irradiation and by cyclophosphamide. J Immunol 117: 1629-1637

16. Mitsuoka A, Baba M, Morikawa S (1976) Enhancement of delayed hypersensitivity by depletion of suppressor T cells with cyclophosphamide in mice. Nature (Lond) 262: 77-78

17. Lagrange PH, Mackaness GB, Miller TE (1974) Potentiation of Tcell-mediated immunity by selective suppression of antibody formation with cyclophosphamide. J Exp Med 139: 1529-1539

18. Askenase PW, Hayden BJ, Gershon RK (1975) Augmentation of delayed type hypersensitivity by doses of cyclophosphamide which do not affect antibody response. J Exp Med 141: 697-702

Received: 13 March 1984

and in revised form: 15 October 1984

Dr. Minoru Harada

Shionogi Research Laboratories

Shionogi \& Co. Ltd.

Fukushima-ku

J-Osaka 553

Japan 